\title{
DIAKRONIKA
}

Vol. 19 No. 1 Th. 2019 p: 1-14

ISSN: 1411-1764 (Print) | 2620-9446 (Online)

http://diakronika.ppj.unp.ac.id

\section{Peranan Perempuan Nelayan Kota Padang dalam Membantu Ekonomi Keluarga}

\author{
Najmi, Azmi Fitrisia \\ najmiunp86@gmail.com \\ Universitas Negeri Padang
}

\begin{abstract}
This research explains the role of women fishermen (fishermen's wife) in assisting family economic needs. Fishermen who have economies below average are considered unable to meet their daily needs. Fishermen are jobs that bear considerable risk. In addition to the many shipping supplies and fishing gear they need, the risk of weather also greatly affects. For example if a storm hit the beach, then they automatically cannot get down to the sea and it is difficult to catch fish. Here the role of women is needed. Automated women cannot always rely on their husband to meet family needs. Here comes the role of two women who are certainly very helpful to the fisherman especially in the economic field. Various jobs such as sewing, trading such as opening a shop and other work. Here also will be found various problems such as women ignore their health and whether there is a role of government in paying attention to this, especially the local government. This research uses field observation method through interview and some data needed such as document as additional material. Interviews were conducted with fishermen and women fishermen at the study sites. Then also use the method of history in general, where data from the results of the interview will also be criticized and analyzed.
\end{abstract}

Keywords: fisherman's wife, women double role, family needs.

\begin{abstract}
Abstrak
Penelitian ini menjelaskan mengenai peranan perempuan nelayan (istri nelayan) dalam membantu kebutuhan ekonomi keluarga. Nelayan dengan kondisi kehidupan ekonomi di bawah rata-rata dianggap tidak dapat memenuhi kebutuhan sehari-hari. Nelayan merupakan pekerjaan yang menanggung resiko cukup besar. Selain banyak perlengkapan perkapalan dan alat penangkapan ikan yang mereka butuhkan, resiko cuaca juga sangat mempengaruhi. Misalnya jika badai melanda pantai, maka nelayan otomatis tidak bisa turun ke laut dan sulit untuk menangkap ikan. Di sini peran perempuan sangat dibutuhkan. Para perempuan otomatis tidak bisa selalu bergantung pada suami mereka untuk memenuhi kebutuhan keluarga. Di sinilah muncul peran ganda perempuan yang tentu sangat membantu para nelayan khususnya dalam bidang ekonomi keluarga melalui pekerjaan seperti menjahit, berdagang membuka warung dan pekerjaan lainnya. Di sini berbagai permasalahan mucul, salah satunya perempuan mengabaikan kesehatannya dan bagaimanakah peran pemerintah memperhatikan hal ini, khususnya pemerintah daerah. Penelitian
\end{abstract}


ini menggunakan metode observasi lapangan melalui wawancara dan beberapa data yang diperlukan seperti dokumen sebagai bahan tambahan. Wawancara dilakukan dengan para nelayan dan perempuan nelayan di lokasi penelitian. Kemudian juga memakai metode sejarah pada umumnya, di mana data dari hasil wawancara nantinya juga dikritik dan dianalisis.

Kata kunci:Perempuan Nelayan, Peran Ganda Perempuan, Kebutuhan Keluarga

This work is licensed under the Creative Commons Attribution-ShareAlike 4.0 International License.

\section{Pendahuluan}

Sebuah penelitian dari sudut pandang pembagian kerja menurut jenis kelamin berkesimpulan bahwa para istri nelayan telah bekerja sepanjang tahun. Pekerjaan memelihara anak, mereka kombinasikan dengan kegiatan-kegiatan ekonomi di tepi pantai (Pomeroy, Pollnac, Katon, \& Predo, 1997). Kemudian dalam tulisan Saliem (1995) tentang Potensi dan Partisipasi Wanita dalam Kegiatan Ekonomi Pedesaan membagi kegiatan di tepi pantai yang telah dilakukan para istri nelayan. Pertama, kegiatan persiapan (menjurai jaring/alat tangkap ikan, menyiapkan bahan-bahan pengawet seperti garam dan es, dan menyiapkan bekal makanan untuk suaminya yang akan pergi melaut). Kedua, kegiatan pengolahan hasil laut (mengasap, memindang, mengasin/pengeringan, mengabon, membuat trasi, kerupuk $\mathrm{dsb}$ ). Ketiga, kegiatan memasarkan hasil (melelang ikan, menjual pada agen dan pengecer). Keempat, kegiatan kerajinan (membuat keranjang, kerajinan kulit kerang, membuat jaring).

Uraian di atas membuktikan bahwa perempuan bekerja bukanlah sesuatu yang mustahil bagi keluarga nelayan. Keterlibatan perempuan dalam menunjang ekonomi rumah tangga telah meluas (Karima, 2017). Bahkan lamanya waktu yang terpakai untuk bekerja telah hampir membuat perempuan lupa akan kesehatan dan kesejahteraan diri sendiri. Kesadaran perempuan nelayan tentang hidup sehat, awet, dan memanjakan diri 'justru' menjadi pertanyaan yang krusial. Tak menjadi berdaya pandangan teori nature dan teori nurture yang menyebutkan bahwa hambatan perempuan dalam bekerja karena faktor biologis dan sosio-kultural (Budiman \& Seksual, 1985). Pandangan teori mothering yang berpikir bahwa pembatasan aktifitas perempuan hanya pada kegiatan rumah tangga disebabkan faktor psikologis internal perempuan, tidak lagi mendapat tempat (Irwan \& Semaan, 1993). Begitu pula hasil penelitian Arundati Shinta yang menyebutkan bahwa agama seperti Islam dan kebudayaan telah menjadi penghambat perempuan untuk bekerja (Shinta, 1993). 
Najmi, Azmi Fitrisia

Peranan Perempuan Nelayan Kota Padangdalam Membantu Ekonomi Keluarga

Pada masyarakat nelayan dorongan perempuan untuk bekerja lebih banyak akibat masalah ekonomi rumah tangga. Menurut Raymond Feith, dari aspek pengembangan usaha bagi nelayan, relatif rendah (Firth, 1975). Hal ini dapat dari perolehan hasil tangkapan yang hanya bila nelayan turun ke laut. Pada musim badai seringkali hasil tangkapan menyusut bahkan nelayan bisa pulang kosong. Alasan ini pulalah menimbulkan kesulitan nelayan untuk merencanakan kehidupannya. Kelebihan pendapatan selama 'musim ikan' habis untuk membayar hutang selama paceklik. Kedua, dengan skala pendapatan demikian menginvestasikan sisa pendapatan sulit. Ketiga, nelayan harus mengeluarkan dana bagi kebutuhan sehari-hari. Tidak lebih baik dari petani yang dapat memenuhi kebutuhan sehari-hari melalui penyeragaman tanaman.

Nelayan di Kota Padang tidak berbeda jauh keadaannya. Kesulitan ekonomi rumah tangga telah menjadi pemandangan umum (Kompas, 1993). Belitan hutang menjadikan mereka terus terbelenggu, statis bahkan stagnan. Peningkatan hidup dan harapan hidup lebih baik masih sebuah 'mitos'. Banyak nelayan tidak mampu keluar dari kemiskinan. Di Kota Padang terdapat $1.190 \mathrm{KK}$ nelayan miskin. Mereka tersebar di 5 kelurahan, masingmasing Pasia Nan Tigo, Purus, Aia Manih, Gates Nan XX dan Teluk Kabung Utara (Haluan, 2015).

Gambaran anak-anak usia sekolah yang bekerja sebagai buruh nelayan bisa kita temukan (Fitrisia, 1996). Pada nelayan Minangkabau ada istilah 'anak ula' yaitu anak-anak yang berada yang dalam usia sekolah dan terlibat dalam usaha penangkapan ikan. Demikian pula ditemui bahwa tingkat pendidikan dari anak-anak nelayan tergolong rendah. Wawancara dengan guru sekolah dasar di Pesisir Selatan menyebutkan bahwa tidak heran bahwa anak-anak sekolah dasar bagaikan 'ayam gadih batalua'. Perempuan nelayan juga terlibat dalam bidang kegiatan perikanan di tepi pantai dan kegiatan-kegiatan di luar sektor perikanan laut seperti membuka warung (Fitrisia, 1998). Disamping kegiatan-kegiatan ini sebagian besar bertujuan untuk membantu ekonomi rumah tangga, tapi diantaranya ada yang merupakan tiang keluarga.Semata merekalah penggerak ekonomi rumah tangga.

Perhatian pemerintah Orde Baru terhadap perempuan telah dimulai. Guna meningkatkan taraf hidup masyarakat nelayan di pedesaan pantai ditemukan lembaga-lembaga sosial kemasyarakatan seperti Posyandu, PKK, Koperasi, KB, dan kelompencapir. Sebagai lembaga informal kehadirannya dipandang mampu meningkatkan kesadaran perempuan. Tetapi secara kualitas peranan lembaga sosial pedesaan ini belum dapat dilihat. Barangkali karena keberadaan lembaga sosial desa ini baru berangkat dari kaca mata pemerintah dan tidak mempertimbangkan adanya yang spesifik dan 
penduduk yang bermata pencaharian sebagai nelayan. Meluasnya peran ganda para istri nelayan justru perlu dihadapi dengan program dan yang membantu kesadaran perempuan akan pentingnya hidup 'sejahtera dan bahagia'. Kerangka pemikiran ini memerlukan analisis historis yang kaya dengan kekuatan kronologi dan perioderisasi, sehingga identifikasi perubahan melalui pertimbangan temporal yang terstruktur (pendekatan diakroniksinkronik).

Permasalahan di dalam kehidupan nelayan di Indonesia masih menjadi sebuah polemik. Nelayan yang identik dengan kemiskinan dan mengharapkan bantuan dari pemerintah tentu selalu menjadi sorotan. Sebut saja surat kabar yang tidak hentinya memberitakan bagaimana persoalan yang ada di dalam kehidupan nelayan. Mulai dari perekonomian nelayan, izin melaut, alat perkapalan yang terbatas, alat penangkapan ikan serta banyaknya syaratsyarat/ketentuan penangkapan ikan hingga faktor alam yang menjadi hambatan nelayan dalam memenuhi kebutuhannya. Berbagai persoalan ini tentu tidak ada habisnya. Di sinilah peranan perempuan sangat dibutuhkan oleh para nelayan. Perempuan yang identik dengan urusan domestik tentu dihadapkan oleh peran ganda yang tidak hanya urusan rumah tangga namun juga membantu suaminya dalam menambah kebutuhan sehari-hari. Penelitian ini akan dibatasi pada peranan perempuan nelayan Kota Padang dalam membantu ekonomi keluarga yang mengalami nasib yang sama dengan perempuan nelayan pada umumnya.

\section{Pembahasan}

Penelitian ini dilakukan pada lima lokasi atau kelurahan Kota Padang. Di lima kelurahan ini ditemukan berbagai macam perbedaan peranan dan jenis pekerjaan perempuan walaupun ada yang sama namun memiliki sedikit perbedaan. Lima kelurahan ini berlokasi di sekitar pantai Kota Padang. Lima kelurahan tersebut yaitu Kelurahan Purus Kecamatan Padang Barat, Kelurahan Pasia Nan Tigo, Kelurahan Aia Manih (Air Manis), Kelurahan Gates Nan XX dan Kelurahan Teluk Kabung Utara.

Kelurahan Purus Kecamatan Padang Barat para istri nelayan masih tidak lepas dari kegiatan perdagangan. Sedikit menguntungkan bagi perempuan di kelurahan ini, wilayah purus merupakan salah satu wisata pantai yang ramai dikunjungi para wisatawan lokal dan luar Kota Padang. Hampir setiap hari lokasi pantai di kelurahan purus dikunjungi oleh masyarakat untuk sekedar berwisata dan menikmati sore-sore di sekitar pantai. Para perempuan nelayan rata-rata berjualan di lokasi wisata tersebut mulai dari buka lapak kecil hingga warung serta kafe-kafe yang setiap hari dikunjungi wisatawan. 
Najmi, Azmi Fitrisia

Peranan Perempuan Nelayan Kota Padangdalam Membantu Ekonomi Keluarga

Pemerintah daerah Kota Padang sudah beberapa tahun ini mulai membenahi wisata pantai di sekitar Purus. Hal ini tentu memberikan dampak positif bagi masyarakat di Kelurahan Purus. Purus yang dahulunya "sembraut" sekarang sudah mulai ditata oleh pemerintah Kota Padang. Banyak ditemukan pedagang perempuan di sekitaran pantai purus. Rata-rata para pedagang juga terdiri dari para istri nelayan dan ada juga para pendatang yang ingin berdagang di wilayah tersebut.

Kelurahan Pasia Nan Tigo terletak di Kecamatan Koto Tangah Kota Padang. Kelurahan ini berada di sepanjang pantai yang juga sebagai lokasi wisata pantai yang disebut Pantai Pasia Jambak. Nelayan yang berada di Pasia Nan Tigo dahulunya adalah asli penduduk di Kecamatan Koto Tangah. Sekarang sudah bercampur dengan nelayan pendatang dari Kabupaten Pesisir Selatan. Hal ini bisa disebabkan oleh berbagai alasan. Misalnya penduduk setempat yang sebagian sudah beralih profesi seperti menjadi pedagang karena profesi nelayan yang sudah tidak menjanjikan dari segi ekonomi, serta kurangnya minat pemuda atau generasi sekarang di bidang kemaritiman terutama menjadi nelayan.

Nelayan pendatang ini biasanya hanya ketika melaut saja. Setelah selesai melaut dan mendapatkan ikan, para nelayan yang rata-rata dari pesisir selatan ini kembali pulang ke kampungnya masing-masing. Ada beberapa nelayan yang akhirnya mengontrak di kelurahan tersebut dan menginap sementara di rumah-rumah penduduk lokal. Selain itu juga ada nelayan yang menyewa pondok sederhana yang dibangun oleh penduduk lokal. Setelah lama melaut di kelurahan ini, nelayan pendatang ini juga ada yang menetap dan menjadi warga tetap kelurahan Pasia Nan Tigo dengan mengurus surat pindah serta membuat KTP menjadi warga Pasia Nan Tigo. Hal ini juga disebabkan oleh beberapa hal seperti menikah dengan penduduk lokal dan memang membawa keluarganya untuk menetap karena juga berhubungan dengan bantuan untuk nelayan yang diberi pemerintah pusat dan daerah (Alizar, 2017).

Di Kelurahan Pasia Nan Tigo perempuan juga berperan dalam kegiatan perikanan laut yaitu pengeringan, pengolahan dan pemasaran ikan kering. Dalam kegiatan ini perempuan lebih banyak berperan dan para nelayan hanya bertugas turun ke laut untuk menangkap ikan. Dalam pembagian tugas rumah tangga perempuan nelayan tidak hanya mengurus urusan domestik namun juga dalam kegiatan perikanan. Penelitian yang ditulis oleh Hikmah tentang Riset Kajian Peran Gender pada Rumah Tangga Masyarakat Nelayan bahwa pembagian tugas perempuan nelayan (istri) dengan para nelayan dibagi berdasarkan alokasi waktu (Hikmah, 2007). 
Alokasi curahan waktu suami (nelayan) terhadap aktivitas produktif lebih besar dibanding istri yaitu sebesar 11,16 jam/hari, sedangkan rata-rata alokasi untuk aktivitas produktif istri nelayan hanya sebesar 5,14jam/hari. Aktivitas domestik alokasi waktu suami rata-rata hanya 3,20 jam/hari, sedangkan alokasi waktu istri untuk kegiatan domestik rata-rata 9,49 jam/hari. Alokasi waktu luang suami 8,02 Jam/hari, dan alokasi waktu luang istri lebih besar yaitu 9,21 jam/hari. Alokasi curahan waktu untuk aktivitas sosial suami rata-rata $2,93 \mathrm{jam} / \mathrm{hari}$, dan alokasicurahan waktu istri untuk aktivitas sosial sebesar 2,00 jam/hari (Hikmah, 2007).

Berdasarkan rata-rata alokasi curahan waktu di atas menunjukkan bahwa peran suami lebih banyak pada aktivitas produktif,sementara istri lebih banyak pada aktivitas domestik. Hal ini menunjukkan bahwa bias gender masih sangat kental mewarnai pola kerja masyarakat nelayan setempat. Adanya ketimpangan gender dalam hal beban kerja, di mana istri memiliki peranganda yaitu sebagai penanggung jawab dalam urusan rumah tangga dan juga membantu suami sebagai pencari nafkah. Istri bekerja, lebih kepada alasan karena kebutuhan ekonomi, bukan berdasarkan pada kesetaraan gender (Hikmah, 2007).

Pembangunan yang bertujuan meningkatkan kualitas manusia seharusnya memperhatikan kondisi perempuan maupun laki-laki atau bersifat gender sensitive. Peran perempuan dapat dioptimalkan apabila faktor penghambat yang melingkupinya teridentifikasi dengan baik. Walaupun secara kuantitatif jumlah perempuan lebih banyak dari kaum laki-laki, belum banyak rencana pembangunan yang benar-benar mendasarkan pada kebutuhan kaum perempuan, padahal mereka bekerja pada dua fungsi sekaligus, reproduktif dan produktif (Hikmah, 2007). Porsi kerja perempuan yang lebih banyak di dalam rumah tangga mengakibatkan beberapa perempuan mengabaikan kesehatannya. Banyak kasus akhirnya perempuan mengalami tekanan psikis dan fisik karena kelelahan bekerja di ruang domestik dan bekerja di luar rumah guna menambah kebutuhan ekonomi keluarga.

Kelurahan Air Manis juga terletak di pinggiran pantai dan di kelurahan ini juga sebagai salah satu tempat wisata pantai dan pulau. Di kelurahan ini jumlah nelayan tidak terlalu banyak dibandingkan dengan kelurahan lain. Hal ini karena penduduknya yang memang tidak terlalu banyak dilihat dari jumlah RW yang hanya 2 buah dan RT sebanyak 6 buah (Miswar, 2017). Walaupun di kelurahan ini jumlah nelayan yang aktif tidak terlalu banyak atau bisa dibilang lebih kurang 40 orang, namun kegiatan perikanan seperti melaut selalu rutin dilakukan oleh nelayan. Terbukti dari aktifnya kelompok 
Najmi, Azmi Fitrisia

Peranan Perempuan Nelayan Kota Padangdalam Membantu Ekonomi Keluarga

nelayan tersebut yaitu ada dua kelompok nelayan yang masing-masing diberi nama "Camar Laut" dan "Batang Baru Mudo"(Iskandar, 2017a).

Salah satu anggota kelompok nelayan dari Batang Baru Mudo bernama Dedi Iskandar. Beliau sudah lama menjadi nelayan atau bisa dibilang sejak usia remaja. Beliau tinggal di pinggir pantai Air Manis. Selama menjadi nelayan, beliau sudah menerima beberapa bantuan. Seperti Dana Pump sebesar Rp. 100.000,-, mesin perahu, alat tangkap, alat pancing, dll. Dedi Iskandar merupakan anggota kelompok nelayan "Batang Baru Mudo". Kelompok ini terbentuk pada tahun 2013. Sebelum kelompok ini terbentuk, sudah ada kelompok Camar Laut, namun para anggotanya terpecah hingga membuat kelompok baru yaitu Batang Baru Mudo. Batang Baru Mudo diketuai oleh Andre dan Camar Laut oleh Asril. Kedua kelompok ini setiap minggunya rutin mendapat penyuluhan dan pembinaan dari dinas kelautan dan perikanan Kota Padang yang dibina oleh Syafril.

Menurut pengakuan Dedi Iskandar, bantuan kepada kelompok nelayan di Kelurahan Air Manis dimulai pada tahun 2014 yaitu dana Pump sebesar Rp. 100.000,-. Selain itu juga bantuan perahu seharga Rp. 6.000.000,- dan mesin Rp. 5.500.000,-. Bantuan ini langsung diberikan kepada kelompok nelayan. Selain itu juga ada bantuan alat tangkap ikan. Pada tahun 2015-2016 tidak ada bantuan sama sekali untuk nelayan. Baru ada lagi tahun 2017 yaitu berupa mesin. Mesin ini biasanya tahan paling lama satu tahun. Bantuan lain juga pernah diterima oleh kelompok nelayan yaitu cat untuk mewarnai perahu dari partai perindo.

Dedi Iskandar biasanya turun ke laut dua kali sehari yaitu pagi dan sore (malam) hari. Beliau sekaligus toke ikan atau pengumpul ikan dari temanteman nelayan yang lain dan hasil tangkapan serta ikan-ikan yang dikumpulkan tersebut langsung dijual ke pasar. Di kelurahan ini tidak ada kegiatan pengeringan ikan atau pengolahan ikan lainnya. Ikan-ikan dari hasil laut langsung dijual atau dikumpulkan ke toke-toke ikan.

Tidak adanya kegiatan pengeringan ikan otomatis pekerjaan sampingan para istri nelayan di luar bidang perikanan. Istri Dedi Iskandar misalnya, bernama Juslaini (43 Tahun). Juslaini bekerja sebagai Ibu Rumah Tangga dan membuka warung kecil-kecilan di sebelah rumahnya. Usaha warung tersebut dimodali dari pinjaman tukang kredit dan juga biaya pribadi dari hasil tabungan yang lama dikumpulkan. Selain Juslaini, istri-istri nelayan yang tinggal di Kelurahan Air Manis rata-rata berjualan kecil-kecil berupa warung dan lapak. Warung dan lapak ini juga dibuka di pulau yang ada di sekitar pantai. Jika ada perayaan seperti lebaran dan hari libur baru banyak pengunjung, namun jika hari biasa pengunjung di pulau dan sekitar pantai 
sangat jarang dan sepi. Usaha lain yang dilakukan oleh istri-istri nelayan di kelurahan ini seperti usaha pengeringan ikan yang disebutkan boleh dikatakan tidak ada. Para istri biasanya banyak bergantung dari suami serta kebanyakan hanya buka warung dan lapak kecil di samping rumah dan sekitar pulau.

Selain Dedi Iskandar, Jasrul salah satu anggota Batang Baru Mudo juga sudah lama menjadi seorang nelayan atau dibilang semenjak beliau remaja. Uniknya beliau sering dibantu oleh istrinya yang bernama Nurleli (45 tahun) turun ke laut. Nurleli bekerja sebagai ibu rumah tangga dan sekali-sekali juga berjualan musiman seperti buka warung ketika lebaran dan hari libur/hari besar lainnya di sekitar pulau dekat kelurahan Air Manis.

Di Kelurahan Gates Nan XX merupakan lokasi yang berdekatan dengan pelabuhan Teluk Bayur. Di sekitar pelabuhan inilah para nelayan melakukan kegiatan penangkapan ikan. Nelayan di kelurahan ini sama halnya dengan kelurahan Pasia Nan Tigo, sebagian nelayan di sini merupakan nelayan pendatang dari Kabupaten Pesisir Selatan. Berbeda dari Pasia Nan Tigo, Kelurahan Gates Nan XX berdekatan dengan perbatasan Kabupaten Pesisir Selatan. Nelayan pendatang dari pesisir biasanya setelah melaut langsung pulang ke kampungnya (ke rumah istrinya) karena jarak Gates Nan XX dengan Kabupaten Pesisir Selatan yang lumayan dekat lebih kurang memakan waktu paling lama satu jam (Evi dan Azizah, 2017).

Di Kelurahan Gates Nan XX terdapat 9 buah RW. Rata-rata setiap RW memiliki nelayan namun dengan pekerjaan atau jenis yang berbeda-beda. RW 01 banyak nelayan yang berprofesi sebagai buruh (buruh nelayan). Buruh nelayan ini bekerja seperti mengangkat air laut agar ikan tidak busuk, karena sebelum diberi es ikan dari hasil tangkapan laut harus selalu terendam air laut. Biasanya upah buruh nelayan ini sebesar Rp. 2000,- per satu ember air laut. Selain buruh nelayan, RW 2 banyak nelayan yang menangkap ikan dengan perahu atau nelayan yang langsung turun ke laut. RW 5 juga ada nelayan perahu dan separuh nelayan buruh. RW 6 rata-rata lebih banyak nelayan pamukek atau menggunakan alat tangkap pukek. RW 7, RW 8 dan RW 9 rata-rata banyak nelayan yang memakai jalo/manjalo (jaring).

Istri-istri nelayan di kelurahan ini memiliki pekerjaan bermacammacam, mulai dari pedagang kecil hingga menengah (di pasar tradisional). Kelurahan Gates ini juga memiliki pusat pasar dan banyak kegiatan perdagangan, di sinilah rata-rata istri nelayan menambah kebutuhan keluarga dengan berdagang, mulai dari berdagang ikan hingga keperluan harian.

Kelurahan Teluk Kabung Utara merupakan kelurahan yang berbatasan langsung dengan Kabupaten Pesisir Selatan. Di kelurahan ini terdapat empat kelompok nelayan, namun hanya satu yang tergolong aktif yaitu Kelompok 
Najmi, Azmi Fitrisia

Peranan Perempuan Nelayan Kota Padangdalam Membantu Ekonomi Keluarga

Nelayan "Cahaya Laut".Cahaya Laut berdiri pada tahun 2005 dengan jumlah anggota 100 orang. Namun jumlah yang cukup banyak ini akhirnya hanya aktif sekitar 30 orang nelayan. Hal ini juga disebabkan oleh beralihnya profesi nelayan karena adanya pendirian BUMN di Kelurahan Teluk Kabung Utara seperti: PLTU dan Pertamina. Sebagian nelayan memilih bekerja di perusahaan tersebut (Asrul, 2017).

Asrul menyebutkan, nelayan di Kelurahan Teluk Kabung bisa dikatakan hidup di bawah garis kemiskinan. Hal ini tidak hanya karena pengaruh cuaca dan hasil tangkapan ikan yang sedikit, namun cara pandang atau pola pikir nelayan yang masih belum maju. Rata-rata nelayan di kelurahan ini melaut hanya untuk kebutuhan sehari-hari dan tidak ada kebutuhan tambahan untuk sekedar ditabung. Asrul adalah nelayan yang sudah merubah mindset tersebut. Beliau selain karena memang berpendidikan di mana beliau juga seorang sarjana, juga berprofesi sebagai nelayan. Beliau tidak malu namun ingin merubah pola pikir masyarakat yang menganggap nelayan masih pekerjaan yang tidak menjanjikan.

Di Kelurahan Teluk Kabung terdapat tiga jenis profesi nelayan yaitu nelayan pukek/payang, nelayan pancing dan nelayan jaring. Nelayan pukek menangkap ikan dengan cara menebar jaring pukek di tengah kaut dan ditarik sama-sama, nelayan pancing dengan memakai pancing dan nelayang jaring menggunakan jaring/jala dengan perahu kecil di pinggirang pantai atau sekitar pantai.Beriringan dengan Cahaya Laut, dulu juga ada kelompok istri nelayan yang juga sama-sama didirikan tahun 2005 yang diberi nama "Srikandi". Namun kelompok ini tidak terlalu aktif dan akhirnya bubar sama sekali. Padahal awal tujuan kelompok ini untuk membina istri-istri nelayan dalam membantu ekonomi rumah tangga, seperti mengadakan pelatihan kegiatan pengeringan ikan. Namun karena modal yang tidak ada, banyak para istri nelayan yang hanya berprofesi sebagai ibu rumah tangga dan usaha lainnya. Bisa dikatakan kegiatan pengeringan ikan tidak ada di kelurahan ini.

Usaha lain para istri nelayan seperti menjahit dan buka warung serta usaha dagang lain seperti membuat "palai ikan". Usaha palai ikan ini ditekuni oleh beberapa istri nelayan salah satunya Nurmai Ayuni (40 tahun). Nurmai sudah menekuni usaha ini lebih kurang 16 tahun. Beliau adalah janda dan suaminya sebelum meninggal adalah seorang nelayan. Suami Nurmai sudah meninggal 12 tahun yang lalu. Dari penghasilan menjual palai ikan inilah Nurmai dan keluarga mencukupi kebutuhannya.

Selain Nurmai, istri-istri nelayan juga ada yang berprofesi sebagai pedagang, yaitu Ida (60 tahun) yang membuat usaha "peyek ikan". Selain itu juga ada yang berprofesi sebagai tukang cuci yaitu Ipit (40 tahun) yang juga 
seorang janda nelayan. Rata-rata usaha istri nelayan sangat beragam dan ada juga yang berladang sayur. Dapat disimpulkan, bahwa kebutuhan keluarga nelayan tidak cukup dari suami saja namun juga dibantu oleh para perempuan (istri) nelayan.

Di lima kelurahan ini nelayan rutin diberi pelatihan dan penyuluhan yang berkaitan dengan kegiatan perikanan. Biasanya yang memberikan pelatihan yaitu tenaga dari dinas perikanan dan kelautan Kota Padang. Salah satunya bernama Syafril. Bantuan pada nelayan juga sudah diberikan oleh pemerintah melalui dinas perikanan dan kelautan provinsi/kota. Seperti bantuan mesin perahu, perahu, alat tangkap, pancing dll. Hal ini lebih banyak pada bantuan operasional untuk nelayan. Dalam hal bantuan khusus pada kaum perempuan nelayan masih sangat jarang. Kebanyakan hanya berupa pelatihan dan penyuluhan di mana perempuan digerakkan untuk memiliki usaha lain selain bergantung dari suami.

Perhatian pemerintah khusus pada perempuan nelayan masih dikategorikan belum ada. Hal ini lebih kepada aspek ekonomi perempuan. Dari segi kesehatan memang sudah ada seperti posyandu dan program dari dinas kesehatan setempat, namun rasanya belum maksimal. Perempuan yang memiliki jam kerja dan peran ganda dibandingkan laki-laki sangat butuh perhatian khusus pemerintah pusat dan daerah. Nelayan yang identik dengan kemiskinan struktural dan turun-temurun, membuat pemerintah harus lebih mendalami masalah tersebut. Walaupun tidak hanya tanggung jawab pemerintah saja, nelayan juga harus perlu diberikan pemahaman akan pentingnya pendidikan. Tidak hanya nelayan, namun juga para perempuan nelayan agar mereka tidak terjebak oleh yang namanya kemiskinan struktural.

Data pada tahun 2017, pemerintah memberikan paket bantuan BBC pada nelayan di Kota Padang. Paket ini ditujukan pada 14 kabupaten dan Kota. Di Sumatera Barat bantuan diperoleh oleh nelayan Kota Padang dan Pasaman Barat. Adapun kriteria nelayan yang mendapatkan bantuan adalah mereka yang memiliki kapal ukuran 5 GT, kapal menggunakan bensin dengan daya 13 HP. Alat tangkap yang digunakan harus ramah lingkungan dan belum pernah menerima bantuan usaha sebelumnya dari pemerintah (Haluan, 2017). Namun sayang tidak terdapat penjelasan apakah yang memperoleh bantuan tersebut nelayan miskin pada kelurahan Bungus Teluk kabung, Purus, Air manis, kelurahan Pasia nan Tigo dan Gates Nan XX. Inilah masalahnya. Selanjutkan meskipun tidak berkaitan dengan peranan pemerintah dalam membantu masyarakat nelayan tapi cukup penting sebagai himbauan agar nelayan turut menjadi laut (Haluan, 2017; Singgalang, 2013). Terutama salah pengrusak terumbu karang dan pencuri ikan yang harus diwaspadai agar ikan samudera Hindia tidak punah. 
Najmi, Azmi Fitrisia

Peranan Perempuan Nelayan Kota Padangdalam Membantu Ekonomi Keluarga

Kebijakan lain dari pemerintah adalah meminta pemilik kapal $30 \mathrm{GT}$ harus mengurus SIPI, segera mendaftarkan kapalnya ke pusat. Di Sumatera Barat disebutkan terdapat kapal di atas 30 GT sebanyak 600 buah. Selayaknya mereka mengurus SIPI (Haluan, 2016). Selanjutnya pemerintah membangun lapak ikan permanen bagi penjual ikan di pantai Padang. Lapak ikan ini berjumlah 30 buah dengan biaya sebesar 1 miliar (Haluan, 2016). Kebijakan budi daya ikan mengatasi larangan bagi kapal bagan melaut di seluruh Indonesia berdasarkan Permen No. 71 tahun 2016 (Singgalang, 2017). Kebijakan ini telah membatasi gerak pemilik kapal bagan bahkan menghentikannya. Permasalahan pengangguran telah menjadi satu tantangan. Lebih-lebih berdasarkan catatan statistik Kota Padang disebutkan sebanyak 121 bagan terdapat di kota ini (BPS, 2015). Akan tetapi nelayan Kelurahan Pasia Nan Tigo gembira karena mendapat kelonggaran dalam pengurusan izin melaut. Mereka tidak takut lagi melaut karena surat izin belum selesai (Metro Padang).

Pemerintah Kota Padang prihatin dengan nasib nelayan kota Padang. Hal ini karena lebih dari 6200 nelayan hanya 1500 yang memiliki alat tangkap. Maka pemerintah memberikan bantuan motor tempel dan alat tangkap rumpon serta fishbox. Akan tetapi kebijakan ini diberikan bukan pada perorangan melainkan kelompok nelayan. Bantuan ini ditujukan pada buruh nelayan. Begitu juga pemerintah tengah mempersiapankan Pelabuhan Pendaratan Ikan Muaro Anak di Kecamatan Koto Tangah. Sedangkan untuk wanita nelayan disediakan outlet untuk menyalurkan hasil olahan ikan (Padang ekspres, 2010).

Potensi laut belum dioptimalkan. Sebuah komentar dari peneliti UBH Padang (Haluan, 2011). Pengembangan potensi kelautan di Sumatra Barat (Sumbar) masih terkendala infrastruktur dan Sumber Daya Manusia (SDM). Sebagai wilayah yang rata-rata berada di pesisir pantai. Sumbar belum mampu untuk memanfaatkan potensi tersebut. Potensi laut Sumbar ini sangat besar, namun keterbatasan infrastruktur dan Sumber Daya Manusia (SDM) menjadi kendala belum dapat termanfaatkan dengan baik potensi tersebut.Dari segi infrastruktur masih banyak kekurangan, baik itu insfrastruktur dari kapal yang masih belum memadai ataupun teknologi yang belum mumpuni serta pelabuhan yang ada. Selain itu, Sumbar juga belum memiliki pabrik-pabrik pengolahan potensi kelautan yang bisa dapat dimanfaatkan masyarakat. Tak hanya dari infrastruktur, Sumbar juga kekurangan Sumber Daya Manusia (SDM). SDM sangat terbatas. Jika hanya mengandalkan nelayan sangat sulit, karena mereka terbiasa melaut dengan cara tradisional, kalau diberikan pelatihan teknologi membutuhkan waktu yang lama (KlikPositif, 2016).. 
Pada tataran nelayan ditemukan informasi bahwa terdapat penyuluh yang membina dan menjadi penyuluh kelompok Nelayan di Kelurahan Air Manis. Tiap minggu beliau melakukan penyuluhan dan pelatihan bagi kelompok nelayan di Kelurahan Air Manis. Beliau juga menyebutkan, bantuan kepada Nelayan selain penyuluhan dan pelatihan tapi juga berupa sarana dan prasana seperti perahu, alat tangkap, mesin, jaring dan pancing. Bantuan yang diberikan bukan aset perorangan namun diberikan kepada kelompok nelayan secara bergiliran. Kelompok nelayan ini dibina agar mampu memelihara sarana dan prasaran yang diberikan. Kelompok nelayan biasanya membayar iyuran kepada kelompok untuk pemeliharaan sarana dan prasarana tersebut. Di Kelurahan Air Manis ini ada dua kelompok yang diberi nama; "Batang Baru Mudo dan Camar Laut. Satu kelompok terdiri dari 10-20 orang (idealnya). Di kelurahan air manis jumlah nelayannya tidak terlalu banyak karena jumlah warga pun tidak terlalu banyak (Syafril, 2017).

Selain itu salah satu nelayan di Kelurahan Air Manis sudah pernah menerima beberapa bantuan. Seperti Dana Pump sebesar Rp. 100.000,-, mesin perahu, alat tangkap, alat pancing dll. Beliau merupakan anggota kelompok nelayan "Batang Baru Mudo". Kelompok ini terbentuk pada tahun 2013. Sebelum kelompok ini terbentuk, sudah ada kelompok Camar Laut, namun para anggotanya terpecah hingga membuat kelompok baru yaitu Batang Baru Mudo. Batang Baru Mudo diketuai oleh Bapak Andre dan Camar Laut oleh Bapak Asril. Kedua kelompok ini setiap minggunya mendapat penyuluhan dan pembinaan dari dinas kelautan dan perikanan Kota Padang . Bantuan kepada kelompok nelayan di Kelurahan Air Manis dimulai pada tahun 2014 yaitu dana Pump sebesar Rp. 100.000,-. Selain itu juga bantuan perahu seharga Rp. 6.000.000,- dan mesin Rp. 5.500.000,-. Bantuan ini langsung diberikan kepada kelompok nelayan. Selain itu juga ada bantuan alat tangkap. Pada tahun 2015-2016 tidak ada bantuan sama sekali untuk nelayan. Baru ada lagi tahun 2017 yaitu berupa mesin. Mesin ini biasanya tahan paling lama satu tahun. Bantuan lain juga pernah diterima oleh kelompok nelayan yaitu cat untuk mewarnai perahu dari Partai Perindo (Iskandar, 2017b). Namun informasi berbeda juga ditemuka dimana adanya nelayan yang belum pernah dapat bantuan dari pemerintah (Jasrul dan Arul, 2017).

\section{Kesimpulan}

Indonesia yang identik dengan konsep nusantara dan terkait dengan kemaritimannya membuat kegiatan di dunia kelautannya sangat berpotensi 
Najmi, Azmi Fitrisia

Peranan Perempuan Nelayan Kota Padangdalam Membantu Ekonomi Keluarga

besar. Selain karena lautan yang luas juga hasil lautnya yang melimpah. Hal ini bertolak belakang dengan kemakmuran rakyat yang tentunya merujuk kepada profesi sebagai nelayan. Nelayan yang memiliki kemampuan melaut tidak membuat mereka menjadi kaya. Nelayan malah banyak memiliki ekonomi di bawah rata-rata termasuk nelayan Kota Padang. Malah profesi ini digeluti oleh masyarakat yang memiliki pendidikan yang cukup rendah. Tidak jarang para nelayan hanya lulusan SD dan SMP. Hanya sedikit yang tamat SMA. Melihat kondisi ini, pemerintah tentunya perlu memberikan perhatian di bidang pendidikan. Selain itu tentu juga memberikan bantuan berupa peralatan perikanan yang harganya cukup mahal dan tidak terjangkau oleh para nelayan.

Tidak jauh berbeda dengan nelayan yang masih hidup di bawah garis kemiskinan, perempuan nelayan juga hampir mengalami nasib yang sama. Perempuan nelayan atau penyebutan lain dari para istri nelayan, harus mampu bertahan dan tidak hanya bergantung dari penghasilan suami saja. Para perempuan otomatis berjuang menambah kebutuhan dengan membantu suami dengan bekerja di luar ranah domestik. Munculnya istilah peran ganda membuat perempuan tidak hanya bekerja di rumah tangga saja namun juga di luar rumah seperti membantu suami menjual ikan dan membuka usaha lain di luar bidang perikanan. Kebutuhan hidup yang semakin meningkat membuat perempuan nelayan harus bekerja dalam memenuhi kebutuhan keluarga. Banyak persoalan yang timbul di saat perempuan mulai bekerja seperti perempuan mulai mengabaikan kesehatannya karena di saat yang bersamaan urusan rumah tangga yang tidak ada habisnya membuat perempuan mempunyai jam kerja yang lebih banyak dibandingkan para nelayan (laki-laki).

\section{Daftar Rujukan}

Alizar. (2017). wawancara dengan Lurah Pasia Nan Tigo, Mengenai Nelayan pendatang 4 Oktober 2017. Padang.

Asrul. (2017). wawancara dengan salah anggota satu kelompok Cahaya Laut, 5 Oktober 2017. Padang.

BPS. (2015). Padang dalam Angka 2014, Badan Pusat Statistik Kota Padang. Padang. https://doi.org/1102001.137

Budiman, A., \& Seksual, P. K. S. (1985). Sebuah Pembahasan Sosiologis Tentang Peranan Wanita di dalam Masyarakat. Jakarta: Gramedia.

Evi dan Azizah. (2017). wawancara dengan staf lurah Gates Nan XX, 5 Oktober 2017. Padang.

Firth, R. (1975). Malay Fishermen Their Peasant Economy. New York: WW Northon \& Company. New York: Inc.

Fitrisia, A. (1996). Nelayan Kenagarian Painan Studi Sejarah Sosial Ekonomi 1970 1995. Padang: Universitas Andalas. 
Fitrisia, A. (1998). Partisipasi Wanita dalam Keluarga Nelayan : Studi Sejarah Sosial Ekonomi di Kenagarian Painan Kabupaten Pesisir Selatan 1970. 1995. Padang: IKIP.

Haluan. (2011, March). Sebuah komentar dari peneliti UBH Padang. HarianHaluan.Com.

Haluan. (2015, March). Anak Nelayan Miskin Sekolah Gratis. HarianHaluan.Com.

Haluan. (2016, January). Surat Kabar. HarianHaluan.Com.

Haluan. (2017). Surat Kabar. HarianHaluan.Com.

Hikmah, D. (2007). Riset Kajian Peran Gender pada Rumah Tangga Masyarakat Nelayan. Padang.

Irwan, A., \& Semaan, I. (1993). Mempersatukan Struktur, Ruang dan Waktu: Sebuah Kritik terhadap Pendekatan Pascastrukturalis" dalam. Prisma (1), Januari 1993.

Iskandar, D. (2017a). wawancara dengan salah satu nelayan, 5 Oktober 2017. Padang.

Iskandar, D. (2017b). Wawancara Mengenai Bantuan di Kelurahan Air Manis, 2 September 2017. Padang.

Jasrul dan Arul. (2017). Wawancara Mengenai Bantuan di Kelurahan Air Manis, 2 September 2017. Padang.

Karima, E. M. (2017). KEHIDUPAN NYAI DAN PERGUNDIKAN DI JAWA BARAT TAHUN 1900-1942. Dikaronika, 1.

KlikPositif. (2016, December). Pelajar Duo Koto Lewati Terjangan Banjir Pakai Perahu Darurat Demi Ujian Semester. Klikpositif.Com.

Kompas. (1993, September). Kesulitan ekonomi rumah tangga. Kompas.Com.

Miswar. (2017). wawancara dengan Lurah Air Manis, 4 Oktober 2017. Padang.

Padang ekspres. (2010, August). Koran Padang ekspres.

Pomeroy, R. S., Pollnac, R. B., Katon, B. M., \& Predo, C. D. (1997).

Evaluating factors contributing to the success of community-based coastal resource management: the Central Visayas Regional Project-1,

Philippines. Ocean \& Coastal Management, 36(1-3), 97-120.

Saliem, H. P. (1995). Potensi dan Partisipasi Wanita dalam Kegiatan Ekonomi Perdesaan. Prisma, 6.

Shinta, A. (1993). Penelitian Mengenai Hambatan Bagi Perempuan untuk Bekerja.

Singgalang. (2013, September). Surat Kabar. HarianSinggalang.Co.Id.

Singgalang. (2017). Surat Kabar. HarianSinggalang.Co.Id.

Syafril. (2017). Wawancara mengenai Batang Baru Mudo dan Camar Laut, 2 September 2017. Padang. 